\title{
Trade and exchange rate policy in sub-Saharan Africa
}

\section{Martin Godfrey}

This article concentrates on three major questions in the area of trade and exchange rate policy raised by the Accelerated Development Report (World Bank 1981) and debate since its publication. First, would increasing the volume of agricultural exports from sub-Saharan Africa (SSA) lead to increased or reduced foreign exchange income for SSA? Second, is food self-sufficiency a sensible (and practicable) aim for SSA? Third, are the conditions for successful devaluation present in SSA?

\section{Increasing Agricultural Exports}

The Accelerated Development Report (World Bank 1981) endorses FAO and OAU targets for growth of African agricultural production as a whole of 3.9 per cent a year for 1980-85 and 4.2 per cent for 1985-90, which would represent a tripling of the growth rate achieved in the 1970s (pp49-50). It also sets out its projections for the growth in the volume of world trade in the 1980s, as in Table 1, with the comment that 'Africa's share of world trade in most commodities could be increased with relatively small effects on prices' (p23). Thus, by implication, growth in output of export crops at rates higher than those shown in Table 1 would result in an increase in foreign exchange income from these crops by SSA.

One defence of this hypothesis needs to be dismissed at the outset as unsatisfactory. This is the suggestion that it was never intended or expected that all SSA countries would follow the advice to increase agricultural exports [Please and Amoako 1983:17].

The advice to increase the volume of agricultural exports was given to the whole of SSA. In judging whether that is sensible advice the question of whether or not it will be followed is irrelevant. The only rational basis for such a judgement is to assume that it will be followed and then assess the consequences. If it were intended that only some countries producing some commodities should follow the advice, while
Table 1

Projected Annual Average Growth Rates in Volume of World Trade in Selected Commodities, 1980-1990 (per cent)

$\begin{array}{lr}\text { Coffee } & 2.3 \\ \text { Cocoa } & 3.7 \\ \text { Sugar } & 2.5 \\ \text { Tea } & 2.5 \\ \text { Groundnuts } & -1.8 \\ \text { Groundnut oil } & 2.1 \\ \text { Palm oil } & 8.2 \\ \text { Beef } & 5.3 \\ & \\ \text { Bananas } & 3.1 \\ \text { Maize } & 1.3 \\ \text { Total Food and Beverages } & 2.8^{1} \\ \text { Timber } & 3.3 \\ \text { Cotton } & 1.0 \\ \text { Tobacco } & 3.5 \\ \text { Rubber } & 3.4 \\ \text { Total Non food Primary } & 2.5^{1} \\ \end{array}$

1 Weighted by percentage share of African merchandise exports, 1976-78.

Sources: Calculated from World Bank 1981: Table 3.6.

others should ignore it, that should have been made explicit, which it certainly is not in the Report.

A fair test of the hypothesis that volume growth will lead to income growth is a comparison, for each commodity, of (a) SSA's share of world exports with (b) world price elasticity of demand for that commodity. If (b) exceeds (a) it can be concluded that SSA can safely expand output and exports of the 
Table 2

Sub-Saharan Africa's Share of World Exports of Selected Commodities Compared with Price Elasticities of Demand

\begin{tabular}{|c|c|c|c|}
\hline & $\begin{array}{l}\text { (1) } \\
\text { Volume of } \\
\text { SSA Exports } \\
1982 \\
\text { ('000 tonnes) }\end{array}$ & $\begin{array}{l}\text { (2) } \\
\text { Share of } \\
\text { World } \\
\text { Exports } \\
1982(\%)\end{array}$ & $\begin{array}{l}\text { (3) } \\
\text { Estimated } \\
\text { Price Elasticity } \\
\text { of Demand } \\
1982\end{array}$ \\
\hline Coffee & 1055 & 27.3 & -0.24 \\
\hline Cocoa & 799 & 65.1 & -0.3 \\
\hline Sugar & 1718 & 5.5 & $-0.05(\mathrm{IC})-0.05(\mathrm{LDC})-0.06(\mathrm{CPE})^{1}$ \\
\hline Tea & 176 & 19.5 & -0.3 (IC) $-0.2(\mathrm{LDC})-0.5$ (CPE) \\
\hline Groundnuts & 151 & 19.9 & $\ldots$ \\
\hline Groundnut Oil & 161 & 39.5 & $\ldots$ \\
\hline Beef & 35 & 1.0 & $\ldots$ \\
\hline Palm Oil & 94 & 2.5 & $\ldots$ \\
\hline Bananas & 189 & 2.7 & -0.1 to 0.6 \\
\hline Maize & 359 & 0.5 & $-0.4(\mathrm{IC})-0.3(\mathrm{LDC}) 0.0(\mathrm{CPE})^{2}$ \\
\hline Cotton & 401 & 9.0 & $\ldots$ \\
\hline Tobacco & 143 & 10.1 & -0.77 \\
\hline Rubber & 138 & 4.5 & $\ldots$ \\
\hline Sisal & 117 & 71.5 & $\ldots$ \\
\hline
\end{tabular}

${ }^{1} \mathrm{IC}=$ industrial countries; $\mathrm{LDC}=$ less developed countries; $\mathrm{CPE}=$ centrally planned economies.

${ }^{2}$ Course grains (including barley, oats, rye, sorghum and millet as well as maize).

Source: Columns (1) and (2), FAO Trade Yearbook, 1982; Column (3), World Bank, Price Prospects for Major Primary

Commodities, Volumes II and III, July 1982.

commodity in question, unless there is a strong presumption that this would lead to a retaliatory increase in exports by non-SSA producers that would not otherwise have occurred. Table 2 assembles all readily available data relevant to this question.

As can be seen, in the case of two commodities, coffee and cocoa, sub-Saharan Africa's share of world exports is higher than world price elasticity of demand. In these two cases an increase in the volume of SSA's exports would certainly lead to a fall in income. Two more commodities, sugar and tea, are on the margin. Even though SSA's share of world sugar exports is small, price elasticities in industrial-country and LDC markets are even smaller. Only in centrally planned economies would an export drive not result in a fall in earnings, and then only narrowly. Such economies also represent the most promising markets for SSA's tea: from the price-elasticity point of view LDCs could not absorb more SSA's tea without a proportional fall in price, and even in industrialcountry markets price elasticity is dangerously low. In two further cases, groundnut oil and sisal, we have no information on price elasticities, but SSA's share of world exports is so high that there is a strong presumption that elasticities will be lower.

In short, in the case of two commodities which account for over 49 per cent of SSA's earnings from agricultural exports, coffee and cocoa, an increase in the volume of SSA exports would definitely result in a fall in earnings. If groundnut oil and sisal are added to the list, the proportion of SSA's agricultural export earnings affected by the fallacy of composition rises to 51 per cent; and if the two commodities on the margin, tea and sugar, are added, it rises to 61 per cent. Moreover, these calculations implicitly assume that the expansion of agricultural exports is costless. If the costs of such expansion were also taken into account, the proportion would be even higher.

This means that those who prescribe an across-theboard increase in the volume of agricultural exports as part of a strategy of structural adjustment for SSA should modify their prescription considerably. The emphasis, rather, should be on diversification of products, from 'high-share' to 'low-share', and of 
markets, from low-elasticity to high-elasticity. Even then institutions adopting a world view would need to guard against substituting a global for a subcontinental fallacy of composition by advising diversification into products which non-SSA exporters are also advised to expand. In the long run, of course, the less efficient producers will be shaken out, but advice that will increase the pain of such a process should surely be avoided.

\section{Food Self-Sufficiency}

The Accelerated Development Report's position on food self-sufficiency is not entirely clear, as Green has pointed out: 'It havers on food self-sufficiency, intuitively supporting it, almost pulling back (e.g. page 65) on the basis of its commitment to letting short run global market prices decide and pushing exports, and also arguing (pages 62-3) that food and export/industrial crops are complementary anyhow' [Green 1983:31].

Please and Amoako stress that: 'self-sufficiency in staple foodstuffs is an objective which the Bank fully accepts' [1983:10], subject to three major qualifications. First, the desirability of achieving total food self-sufficiency, regardless of cost, the effect on demand of subsidies and the nature of the beneficiaries, is questioned. Second, research into basic foodcrops needed to shift comparative advantage away from export crops will take time and, meanwhile, it will be necessary to import some staple food. Third, food and export crops appear to be complements rather than substitutes, which suggests that policy (e.g. on pricing) should be concerned with the agricultural sector as a whole, and that increases in the efficiency of exporting arrangements could also benefit food output.

Sender and Smith on the other hand maintain that 'what matters is how much people have to eat, which is not determined by whether countries import food or not' [1984:8]. Most economists would agree in principle with that statement, which is in the same spirit as Sen's point that famines reflect not inadequate food production but inadequate 'entitlements' to food on the part of the hungry [Sen 1980].

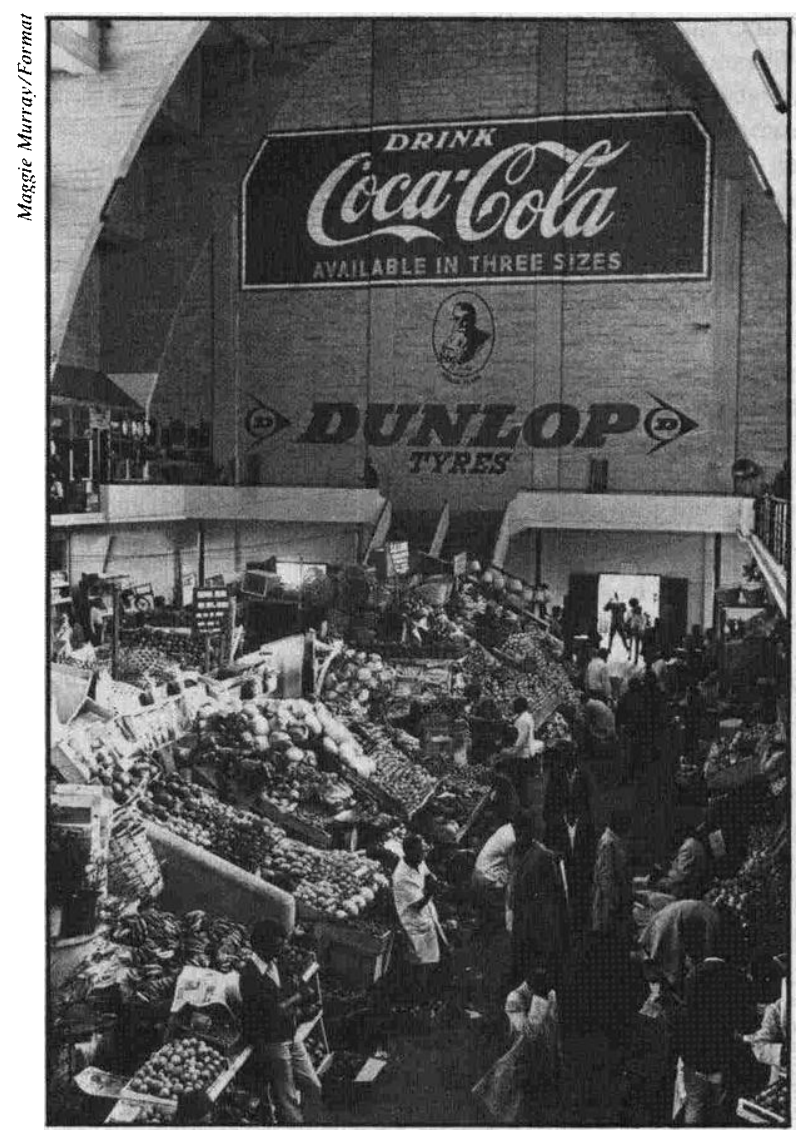

Market gardening thrives in Nairobi. 
African heads of state take a different view, however. The Lagos Plan of Action, endorsed by them in 1980, identified as the objective for the first half of the decade that of bringing about 'an immediate improvement in the food situation and[laying] the foundations for the achievement of self-sufficiency in cereals and in livestock and fish products' [United Nations 1980:12]. The heads of state put particular emphasis on the need for food security: "urgent steps should be taken by every Member State to adopt a coherent national food security policy. National policies must be translated into concrete actions such as early construction of storage facilities, creation of grain reserves, improvement of grain stock management and better forecasting and early warning systems' [ibid.:13].

Like the many other governments in the world which try to limit food imports, African governments want self-sufficiency in staple foods for a variety of reasons of varying credibility. For one thing, food, the ultimate basis of survival in a sense that other commodities are not, is a weapon of international politics and, as governments see it, vulnerability and susceptibility to pressure are increased by a need to import it on a large scale. These strategic/political worries are reinforced by the volatility and unreliability of the far from competitive world grain market [see World Bank 1982:55] which make domestic production look the safest basis for food security. Internally governments are concerned about the adverse consequences for them of failing to ensure an adequate supply of staple food of the type which is currently demanded. The food that is available on the international market often does not correspond exactly to local tastes. In Kenya, for instance, American yellow maize of the type that is imported during recurring food crises is thought fit only to be fed to cattle. Of course, tastes are changing away from traditional staples, but, meanwhile, shortages and food queues are not seen as the best recipe for political survival.

In any case, if food and export crop production are complementary [World Bank 1981; Please and Amoako 1983], the economic cost of achieving the partly political objective of staple food self-sufficiency may be fairly small. In this respect the argument that 'the SSA countries which increased food imports most rapidly in the 1970s were among the fastest growing' [Sender and Smith, 1984:8] is weak. Of Kenya, Ivory Coast, Nigeria and Ghana, for example, only Nigeria shows a strong secular upward trend in cereal imports, as Table 3 shows.

Apart from this special case, which suffered its own version of the 'Dutch disease' (de-agriculturalisation due to a surfeit of oil-based foreign exchange), fluctuations in food imports seem to be more closely related to fluctuations in weather than to anything else. Until the droughts of the late 1970s and early 1980s Ghana's food imports were growing at least as fast as the Ivory Coast's and faster than Kenya's. Moreover, if food self-sufficiency is taken to mean self-sufficiency in basic foodcrops, this point becomes even stronger. Consider, for instance, the pattern of Kenya's imports of maize, as shown in Table 4.

This is the pattern of a basically maize-self-sufficient economy (which in fact exports substantial quantities in most years) which from time to time runs into crises. For instance the huge, temporary imports of maize in 1980 and 1981 reflect managerial ineptitude in a single year $(1979 / 80)$, when huge accumulated stocks were exported by the marketing board at a time of sudden, acute, local shortage.

Table 3

Volume of Cereal Imports, Selected African Countries, 1970-1982

('000 tonnes)

\begin{tabular}{lrrrrrrrrrrrrr}
\hline & 1970 & 1971 & 1972 & 1973 & 1974 & 1975 & 1976 & 1977 & 1978 & 1979 & 1980 & 1981 & 1982 \\
\hline $\begin{array}{l}\text { Kenya } \\
\text { Ivory }\end{array}$ & 2.7 & 6.3 & 7.2 & 5.1 & 1.5 & 8.6 & 1.2 & 6.0 & 10.0 & 2.2 & 38.7 & 14.9 & 19.4 \\
Coast & 18.4 & 13.1 & 17.2 & 29.2 & 17.5 & 8.2 & 12.1 & 31.8 & 30.8 & 36.1 & 46.9 & 57.3 & 59.2 \\
Nigeria & 31.8 & 44.9 & 35.6 & 44.2 & 38.9 & 47.7 & 86.2 & 139.8 & 200.8 & 133.3 & 177.6 & 244.1 & 228.0 \\
Ghana & 14.3 & 8.5 & 11.3 & 14.1 & 17.7 & 8.5 & 10.9 & 29.0 & 26.9 & 19.5 & 21.1 & 25.9 & 21.1 \\
\hline
\end{tabular}

Source: FAO Trade Yearbooks. 
Volume of Maize Imports, Kenya, 1970-82

('000 tonnes)

\begin{tabular}{llllllllllllll}
\hline 1970 & 1970 & 1971 & 1972 & 1973 & 1974 & 1975 & 1976 & 1977 & 1978 & 1979 & 1980 & 1981 & 1982 \\
\hline & 14.3 & 29.1 & 0.1 & 0.1 & 0.7 & 0.4 & 0.03 & 0.03 & 0.08 & 0.02 & 323.9 & 77.4 & 0.0 \\
\hline
\end{tabular}

Source: FAO Trade Yearbooks.

In short, attempts to show that the SSA countries which increased food imports most rapidly in the 1970 s were among the fastest growing do not seem to be helpful to the argument that food imports (and particularly staple food imports) are a Good Thing.

\section{Exchange Rate Policy}

Devaluation, described as 'a powerful tool for restructuring relative prices and incentives' [World Bank 1981:30] is a central element in the Accelerated Development trade and exchange rate policy package. It is preferred to alternatives such as export subsidies on the grounds that it is likely to involve a less severe fiscal and administrative burden. The claims that are made for it are virtually irresistible:

Devaluation permits higher prices to be paid to exporters without subsidies. If tariff reduction and relaxation of import restrictions are accompanied by devaluation, prices for import-substitute production can remain constant in local currency, thus easing adjustment for local producers. Devaluation, combined with tariff reduction or relaxation of import restrictions, enables the full effect of the exchange-rate change to be concentrated on exports [World Bank 1981:30].

Please and Amoako stress the 'widespread failure to recognise that exchange rate policy is one of the most pervasive instruments of development policy' [1983:22].

They make the interesting point that the objectives of food self-sufficiency and African economic integration, emphasised in the Lagos Plan of Action, will be difficult to achieve if the foreign exchange to buy food and manufactured goods from non-African sources continues to be so cheap and, therefore, imported goods are so frequently at a price advantage over domestic output and over goods from other African countries. 'African integration', they suggest, 'can only be encouraged by making it more profitable for consumers, farmers, artisans, industrialists within African countries to trade with each other rather than with the rest of the world' [Please and Amoako 1983:23].

Sender and Smith also accuse critics of Accelerated Development of having a dogmatically negative attitude towards devaluation and, therefore, of avoiding consideration of 'the most important question, which is: under what circumstances would devaluation increase foreign exchange earnings?' [1984:9]. Most important, perhaps, they stress the need to analyse the domestic inflationary consequences of devaluation, as well as its contractionary implications:

There are countries which can devalue effectively, as shown by a considerable change in their balance of payments. There are also other countries which cannot devalue effectively because they lack the necessary discipline to keep money costs under control in the face of increased prices of imports [Lewis 1972:235].

The question is whether the countries of SSA belong to the first category of potentially effective devaluers or to the second. The Accelerated Development Report is optimistic on the basis of experience in non-SSA developing countries [World Bank 1981:30]. It cites a study by Cooper (1971) of 24 devaluations which found that, on average, consumer prices increased by less than half the amount of the devaluation in the following year, while manufacturing wages increased by less than one fourth; and another by Krueger (1978) which found that devaluation tended to reduce inflation rates below what they would otherwise have been.

Actual experience in SSA countries appears to be less promising. The World Bank's 1983 progress report on SSA [World Bank 1983:9] concludes that exchange rate changes in African economies: 
Nominal and Real Effective Exchange Rate Changes, Selected African Countries, 1977-82

\begin{tabular}{lrrrrrrrr}
\hline & \multicolumn{3}{c}{ Nominal } & \multicolumn{3}{c}{ Effective Exchange Rate } & \multicolumn{3}{c}{ Real Effective Exchange Rate } \\
& 1977 & 1980 & 1981 & 1982 & 1977 & 1980 & 1981 & 1982 \\
\hline Kenya & 100 & 98 & 91 & 84 & 100 & 108 & 100 & 100 \\
Mauritius & 100 & 76 & 73 & 70 & 100 & 100 & 97 & 95 \\
Madagascar & 100 & 104 & 97 & 78 & 100 & 113 & 122 & 133 \\
Somalia & 100 & 90 & 75 & 58 & 100 & 142 & 153 & 124 \\
\hline
\end{tabular}

Source: World Bank 1983. Table 5, page 9.

have been widely negated by the failure to hold other incomes in check thus leading to an inflationary situation. This conclusion is particularly worrying in respect of countries such as Kenya, Mauritius, Somalia and Madagascar (see Table 5 below), which have been pursuing a relatively active exchange rate policy but where quite large depreciations in nominal effective rates have still left the real effective rate either appreciated or only slightly devalued.

The differences between the changes in these nominal and real effective rates are attributable to differences in rates of price inflation between the SSA countries and their trading partners. Table 6 isolates one element in this process, domestic price inflation, and compares the progress of exchange rate and consumer price indices for three of the 'active-exchange-ratepolicy' countries over the $1977-83$ period, with monthly indices for 1981 onwards.

For Kenya and Mauritius the value of the domestic currency vis-à-vis the dollar has drifted downward throughout the period. In addition, four devaluations can be identified from the Table: between September and October 1981 and between November and December 1982, in the case of Kenya; between August and September 1981 in Mauritius; and between June and July 1982 in Somalia.

The speed with which the devaluations have been eroded by domestic price inflation has varied. The September 1981 devaluation in Kenya resulted in a 9.4 per cent increase in the shilling price of the dollar in the following month and by September 1982 the rate of increase in this price over a year earlier was 16.8 per cent. The annual rate of increase in consumer prices over the same period was 22.3 per cent, more than negating the devaluation. Moreover, in Kenya's case there was an acceleration of domestic price inflation. By August 1982 the annual rate of inflation was almost 11 percentage points higher than it had been a year earlier. This is consistent with the hypothesis that the devaluation added enough to the inflation rate to negate itself within less than a year.

The experience of Mauritius and Somalia was less extreme. In Mauritius the August 1981 devaluation produced an initial 18.1 per increase in the rupee price of the dollar and by August 1982 the rate of increase in this price over a year earlier was 25.3 per cent. The annual rate of increase in consumer prices over the same period was only 11.3 per cent, and by June 1983 it was only 5.3 per cent. In Somalia, the June 1982 devaluation was much larger, raising the shilling price of the dollar by 141.6 per cent. In the first year after the devaluation consumer prices rose by only 35 per cent. Thus in these two cases the process of erosion of devaluation by domestic inflation seems to have been arrested.

These experiences suggest that dogmatic views, whether negative or positive, about the possibility of effective devaluation in SSA are unwarranted and that a detailed comparative study of these cases and others would be worthwhile. Such a study would throw light on, among other things, the mechanism whereby devaluations are transmitted to domestic price levels. One such mechanism that is often emphasised, real wage resistance, does not seem to have been important, at least in the Kenyan and Mauritian cases, to judge from Table 6 .

Between 1977 and 1982 real manufacturing wages in Kenya fell by 18.4 per cent and in Mauritius by 14.1 per cent. Between 1981 and 1982, when Kenya's nominal effective exchange rate fell by 7.7 per cent and Mauritius's by 4.1 per cent, their real manufacturing 
Indices of Non-agricultural and Manufacturing Wages, Kenya and Mauritius, 1977-82

$$
(1977-100)
$$

\begin{tabular}{ccccccc}
\hline & 1977 & 1978 & 1979 & 1980 & 1981 & 1982 \\
\hline Kenya - non-agricultural & 100.0 & 108.1 & 117.8 & 131.7 & 154.3 & 163.0 \\
manufacturing & 100.0 & 105.0 & 110.9 & 128.0 & 142.3 & 158.0 \\
Mauritius - non-agricultural & 100.0 & 117.4 & 128.6 & 158.0 & 181.1 & 187.9 \\
manufacturing & 100.0 & 117.2 & 122.9 & 163.1 & 187.9 & 193.1 \\
\hline
\end{tabular}

Source: H.O Yearbook of Labour Siatistics.

wages fell by 7.8 per cent and 7.7 per cent respectively. Clearly in neither country are money wage increases, in compensation for devaluation-induced import price increases, an adequate explanation for the consumer price increases that followed. Nor do available data on CPI indices and wage rates elsewhere in SSA since 1979 suggest that they are in any way atypical.

A more convincing explanation, at least in Kenya's case, may be in terms of the capacity of producers to pass on quickly increases in the costs of imported inputs to consumers. In early 1982 several Kenyan manufacturers cited the devaluation as a direct cause of price increases. For instance, the managing director of Firestone (EA) Ltd, which has a monopoly of the Kenyan home market, attributed a 14 per cent price increase to an increase of around 18 per cent in the price of imported petrochemicals as a result of the devaluation. The lag between devaluation and price increase was only 10 weeks, the time taken for raw material inventories to be exhausted (The Standard, Nairobi, 20 February 1982). If the devaluation had been accompanied, as the Accelerated Development Report envisaged, by a relaxation of import restrictions, this might have made it more difficult for manufacturers to pass on price increases. But, as is usually the case, the background to this devaluation was one of acute foreign exchange crisis and tightening of import restrictions. In any case ways of increasing the competitiveness of the import-substituting sector which will not pose an immediate threat to its survival need to be found [see Godfrey 1983] and are, perhaps, a precondition for effective devaluation in some countries

\section{Conclusions}

This article represents clearing of ground for future empirical work rather than an attempt to reach definitive conclusions, but several suggestive results have emerged.

First, the accusation that the Accelerated Development Report in its prescription for SSA to increase the volume of its agricultural exports is guilty of the 'fallacy of composition' is substantially correct. More than 60 per cent of SSA's agricultural export earnings appear to come from commodities for which price elasticity of demand is such that an increase in export volume would reduce export earnings. Thus the emphasis should, rather, be on diversification of agricultural exports and of markets rather than on mere expansion.

Second, food self-sufficiency is an understandable aim and self-sufficiency in basic foodcrops may be the safest basis for food security. Attempts to show that the SSA countries which increased food imports most rapidly in the 1970s were among the fastest growing are found to be unconvincing.

A review of the devaluation experience of three SSA countries which have been pursuing a relatively active exchange rate policy suggests that dogmatic views, whether negative or positive, about the possibility of effective devaluation in SSA are unwarranted. The Kenyan September 1981 devaluation added enough to the inflation rate to negate itself in less than a year. In Somalia and Mauritius, on the other hand, the process of erosion of devaluation by domestic inflation seems to have been arrested. Real wage resistance does not seem to have been an important mechanism in the process whereby devaluations are transmitted to domestic price levels.

\section{References}

Cooper, R. N., 1971, 'Devaluation in developing countries', 
in Gustav Ranis (ed), Government and Economic Development, Yale, U. P., New Haven

Godfrey, M., 1983, 'Export orientation and structural adjustment in sub-Saharan Africa', IDS Bulletin, vol 14 no 1

Green, R., 1983, 'Incentives, policies, participation and response: reflections on World Bank "Policies and Priorities in Agriculture", IDS Bulletin, vol 14 no 1

Krueger, A. O., 1978, Liberalisation Attempts and Consequences, Ballinger, Cambridge (Mass)

Lewis, W. A., 1972, 'Four steps to full employment', International Development Review, vol 14 no 2

Please, S. and K. Y. Amoako, 1983, 'Sub-Saharan Africa the World Bank's agenda for action revisited', paper for
SID Kenya conference, World Bank, (mimeo)

Sen, A., 1981, Poverty and Famine: an Essay on Entitlentent and Deprivation, Clarendon, Oxford

Sender, J. and S. Smith, 1984, 'What's right with the Berg Report and what's left of its critics?' Discussion Paper 192, IDS, Sussex

United Nations, 1980, Lagos Plan of Action (Adopted by the Heads of State and Governments of the Organisation of African Unity), UN A/S-11/14, dated 21 August

World Bank, 1981, Accelerated Development in sub-Saharan Africa: an Agenda for Action, Washington

—1982, World Development Report, Washington

-1983, Sub-Saharan Africa: Progress Report on Development Prospects and Programs, Washington 